КОМУНІКАТИВНА КОМПЕТЕНТНІСТЬ КОНЦЕРТМЕЙСТЕРА ЗАКЛАДУ ВИЩОЇ ОСВІТИ ЯК УМОВА УСПІШНОЇ ПРОФЕСІЙНОї ДІЯЛЬНОСТІ

\title{
COMMUNICATIVE COMPETENCE OF THE CONCERTMASTER IN THE HIGHER EDUCATIONAL INSTITUTION AS A CONDITION OF SUCCESSFUL PROFESSIONAL ACTIVITY
}

y cmammi проаналізовано окремі теоретичні та практичні питання комунікативної компетентності концертмейстера закладу вищої освіти, що пояснюється необхідністю адаптуватись до змін, які відбуваються в галузі сучасної музичної педагогіки. Проаналізовано зміст комунікативної компетентності концертмейстера як однієї з умов успішної просресійної діяльності сучасного фрахівця. Зазначено, що високий рівень комунікативної компетентності дає змогу концертмейстеру здійснювати пошук ефективних підходів у власній практичній діяльності. Визначено структуру комунікативної компетентності концертмейстера, яка складається з комунікативних здібностей, комунікативних умінь, комунікативних знань. Підкреслено, що діяльність концертмейстера в процесі різнобічного педагогіч ного спілкування відбувається у складній системі відносин «викладач - студент концертмейстер», саме тому від його комунікативної компетентності залежать легкість, результативність встановлення контактів у класі, ефективність вирішення різноманітних творчих задач. Доведено, що показниками комунікативної компетент ності концертмейстера $є$ такі: культура вербальної і невербальної комунікації; експресія - вираження почуттів, переживань, виразності; культура партнерської взаємодіі; конфрліктна компетенція; наявність психологічних знань щодо закономірностей розвитку міжособистісних відносин і технологіі їх цілеспрямованого формування; наявність творчого підходу до системи педагогічно доцільних взаємин; здатність до конструктивного вирішення конфліктів і протиріч наявність знань із психології спілкування. Визначено умови, які забезпечують становлення комунікативної компетентності концертмейстера. Зроблено висновок, що комунікативна культура концертмейстера $\epsilon$ складним ореноменом, який удосконалюється впродовж педагогічної взаємодії 3 усіма суб'єктами освітнього процесу та стає чинником успішної професійної діяльності фрахівця

Ключові слова: кониертмейстер, професійна компетентність концертмейстера, комунікативна компетентність концертмейстера, структура комунікативної компетентності концертмейстера, показники комунікативної компетентності концертмейстера

The article analyzes some theoretical and practi$\mathrm{cal}$ issues of the communicative competence of the concertmaster in the institution of higher education, which is caused by the need to adapt to the changes taking place in the field of contemporary music pedagogy. The content of the communicative competence of the concertmaster as one of the conditions for the successful professional activity of a modern specialist is analyzed. It is noted that the high level of communicative competence enables the concertmaster to find effective approaches in his practical activity. The structure of the communicative competence of the concertmaster, which consists of communicative abilities, communicative skills, communicative knowledge, is determined. It is emphasized that the activity of the concertmaster in the process of versatile pedagogical communication takes place in a complex system of teacherstudent-concertmaster relationship, that is why the effectiveness of establishing contacts in the classroom, the effectiveness of solving various creative tasks depends on his communicative competence. It is proved that there are some indicators of communicative competence of the concertmaster: culture of verbal and non-verbal communication; expression - expression of feelings, emotions, expressiveness; a culture of partnership; conflicting competence, the presence of psychological knowledge about the patterns of development of interpersonal relationships and technology of their purposeful formation; having a creative approach to the system of pedagogically appropriate relationships; ability to constructively resolve conflicts and contradictions; knowledge of the psychology of communication. The conditions for ensuring the communicative competence of the concertmaster are defined. It is concluded that the communicative culture of the concertmaster is a complex phenomenon, which is perfected during the pedagogical interaction with all subjects of the educational process and becomes a factor of the successful professional activity of a specialist.

Key words: concertmaster, professional competence of concertmaster, communicative competence of concertmaster, the structure of communicative competence of concertmaster, indicators of communicative competence of concertmaster.
Постановка проблеми у загальному вигляді. Однією з умов успішної професійної діяльності сучасного фрахівця $€$ його компетентність. Закон України «Про вищу освіту» роз'яснює «якість вищої освіти як сукупність якостей особистості з вищою освітою, що відображає її профресійну компетентність, ціннісні орієнтації, соціальну спрямованість і зумовлює здатність задоволь- няти як особисті духовні і матеріальні потреби, так і потреби суспільства». В умовах сьогодення суспільство має потребу у високоосвічених, сумлінних срахівцях, які спроможні самостійно приймати відповідальні рішення у складних обставинах, здатні вирішувати проблеми, що виникають у ситуаціях, пов'язаних із професійною діяльністю, прогнозуючи їх можливі наслідки, відкриті 
до співпраці, що відрізняються мобільністю, конструктивністю, оптимізмом. Такий підхід сприяє становленню компетентного, тобто обізнаного в якійсь галузі фрахівця. У зв'язку з цим проблема впровадження компетентнісного підходу до галузі освіти, нових вимог до концертмейстера, котрий, окрім опанування низки фрахових знань, умінь та навичок, має володіти певними компетентностями, стає досить актуальною.

Аналіз останніх досліджень і публікацій. У сучасній науковій літературі застосовують різні поняття, пов'язані з компетентністю, а саме: «компетентнісний підхід», «компетентнісна модель навчання», «ключові компетентності», «професійна компетентність», «комунікативна компетентність» та інші. Проблему компетентності як важливого показника професійної діяльності досліджували Л. Пляка, Л. Скалій, В. Тюріна та ін. [8; 9]. Американські вчені Н. Хомський [10], Д. Хаймс, Р. Уайт та ін. розуміють компетенцію як «найважливішу поведінкову ознаку, яка $є$ свідком ефективної та успішної дії і яка залежить від контексту дії, організаційних чинників і чинників середовища, а також умов професійної діяльності». У своєму визначенні науковці зосереджуються не стільки на особистісних характеристиках, скільки на властивостях саме діяльності. Найважливіше питання, на якому вони зосереджують свою увагу, - визначення головних елементів діяльності, що мають бути виконані і завдяки яким відбудеться досягнення результату відповідно до поставлених завдань. Прихильники цього підходу пов'язують компетенції з поведінковими властивостями, такими як самосвідомість, саморегуляція, соціальні навички, і вважають, що вони в змозі бути сорормованими впродовж навчання та розвитку. Британським ученим Дж. Равеном компетенція тлумачиться як життєвий успіх у соціально значущій для особистості галузі. Він виокремив понад 35 видів компетентностей, які ототожнює 3 «мотивованими здібностями»: здатність до самоосвіти, самоконтроль, критичне мислення, готовність до вирішення складних проблем, впевненість у собі, наполегливість, здатність до спільної роботи, особиста відповідальність тощо. Нові професійно-технічні комунікації, що розробляються в межах цього підходу, ґрунтуються на профресійних стандартах компетентності за принципом фрункціонального аналізу досліджень у різних контекстах [4, с. 25]. І. Зимня під компетенцією розуміє внутрішні, потенційні, приховані психічні новоутворення (знання, уявлення, програми дій), які свідчать про компетентність особистості. Дослідниця визначає «компетентність» як «інтелектуально і особистісно зумовлену соціально-професійну рису людини, її особистісну якість, яка ґрунтується на знаннях та досвіді» [4, с. 29-30]. На думку Е. Зеєра, компетентність - це глибоке, досконале знання людини виконуваної роботи, способів і засобів досягнення визначеної мети, а також наявність відповідних умінь і навичок; сукупність знань, що дозволяють міркувати про що-небудь зі знанням справи. Отже, професійну компетентність можна розглядати як системну, інтегративну єдність інтелектуальних і знаннєвих складників (узагальнені знання, вміння, навички), особистісних характеристик (ціннісні орієнтації, здібності, риси характеру, готовність до здійснення діяльності тощо) і досвіду, що дає змогу людині використовувати власні ресурси, здійснювати складні види діяльності, своєчасно й успішно адаптуватися в професійної діяльності. Профресійна компетентність концертмейстера не зводиться до окремих якостей особистості, їх сукупності або до певних знань, умінь, навичок. Вона свідчить не тільки про наявний у фрахівця потенціал і здатність його використовувати, але й породжує нові явища, якості життя і діяльності, що сприяє успішній профресійній діяльності.

Мета статті полягає у визначенні структури й показників комунікативної компетентності концертмейстера закладу вищої освіти.

Виклад основного матеріалу. Однією з важливих складових частин професійної компетентності концертмейстера $€$ комунікативна компетентність. Основними джерелами придбання комунікативної компетентності є: мова спілкування, досвід міжособистісного спілкування в офріційному, повсякденному середовищі, загальна ерудиція, навчання спілкування та ін. 3 цих джерел утворюється складний комплекс комунікативних знань і навичок, що становлять комунікативну компетентність. Цей комплекс містить:

- знання культурних традицій, звичаїв, етикету спілкування; чемність, вихованість; орієнтацію в комунікативних засобах, властивих національному світосприйняттю та ін. [5];

- високий рівень мовного розвитку, що дає змогу людині під час спілкування вільно сприймати і передавати інформацію. На думку С. Максименка, комунікативна компетенція - це знання, вміння і навички, вкрай необхідні щодо розуміння власного оточення та створення індивідуальної програми мовленнєвої поведінки, адекватної цілям, межам, обставинам спілкування. Вона містить: знання визначальних категорій мови - стилю, типу, засобів зв'язку речень у тексті та ін.; вміння і навички аналізу тексту; комунікативний досвід вміння і навички мовного спілкування стосовно до різних обставин і умов спілкування з огляду на поставлену мету [5];

- розуміння невербальної мови спілкування (сміх, оплески, жести, міміка, пози, рухи, ситуативна адаптивність);

- вміння вступати в контакт з оточенням, враховуючи їхні вікові, соціально-культурні, статеві, статусні особливості; 
- соціальні норми, реноме, освоєння досвіду спілкування та ін.

Питання комунікативної компетентності розглядаються в роботах Ф. Бацевича, М. Заброцького, І. Зязюна, Н. Волкової, Т. Вольфовської, О. Гойхман, Т. Гордієнко, Н. Драгомирецької, Ю. Ємельянова, А. Зарецького, Н. Казарінова, В. Куніцина, Л. Петровської, О. Пометун, Е. Сидоренко, С. Сисо$€ в а$, Т. Щербан та інших науковців, які визначають їі як сукупність навичок і умінь, необхідних для еорективного спілкування (Л. Петровська); як ситуативну адаптивність і вільне володіння вербальними і невербальними (мовними і немовними) засобами соціальної поведінки (Ю. Ємельянов), як знання, вміння і навички, необхідні для створення власної програми мовленнєвої поведінки, адекватної цілям та ситуаціям спілкування. Ми розглядаємо комунікативну компетентність концертмейстера як змогу використовувати необхідні знання та вміння в процесі вирішення питань, пов'язаних із профресійним спілкуванням. Компонентами структури комунікативної компетентності концертмейстера $€$ такі:

- комунікативні здібності;

- комунікативні вміння;

- комунікативні знання, які мають бути адекватними комунікативним завданням і достатніми для їх вирішення;

- профресійне мислення;

- комунікативний досвід [6, с. 47-48]

До комунікативних здібностей концертмейстера зараховуємо загальні здібності, які пов'язані з багатьма підструктурами особистості і свідчать про його уміння вступати в мовленнєвий контакт із студентами та іншими членами колективу та здатність налаштовувати процес спілкування, спираючись на особливості комунікативної ситуації. Комунікативні уміння $€$ одними 3 основних компонентів профресійної майстерності (Н. Кузьміна, О. Абдулліна), проте їх тлумачення, на думку І. Риданової [7], обмежене соціально-психологічними чинниками, позбавлене істотної розмаїтості. Дослідниця більш ретельно конкретизувала це поняття і визначила блоки професійно-комунікативних умінь: соціально-психологічний, моральноетичний, естетичний, технологічний. До структури соціально-психологічного блоку профресійно-комунікативних умінь концертмейстера зараховуємо: вміння налаштовувати студента на спілкування; створення сприятливого враження (самопрезентаційне вміння); здатність до рефлексії; адекватне сприйняття й розуміння індивідуальності особистості студента; прогнозування розвитку міжсуб'єктних відносин; використання вербальних та невербальних механізмів комунікативного впливу (переконання, навіювання, ідентифікація) [7, с. 147]. Морально-етичний блок профресійнокомунікативних умінь концертмейстера уособлює вміння будувати спілкування на гуманних, демократичних принципах, керуватися правилами професійної етики та етикету, поважати особистісну гідність студента, плідно творчо співпрацювати 3 викладачем та студентом, ініціювати сприятливий психологічний клімат на заняттях. До естетичного блоку професійно-комунікативних умінь концертмейстера зараховуємо вміння узгодити внутрішні й особистісні прояви, артистизм, естетичну виразність, долучення студентів до високої культури спілкування, активізацію емоційного стану та оптимістичне світовідчуття, переживання радості спілкування, почуття прекрасного [1, с. 15-17]. Технологічний блок профресійно-комунікативних умінь концертмейстера визначає вміння використовувати навчальновиховні засоби, методи і прийоми, різноманіття фрорм взаємодії, вибір оптимального стилю спілкування, дотримання педагогічного такту. Для органічного поєднання комунікативної і предметної взаємодії, забезпечення її виховної ефективності концертмейстерові необхідно мати комунікативні знання - це знання про те, що таке спілкування, його сутність, види, закономірності розвитку, які методи і форми використовуються, яке їхнє призначення, можливості, які дії вони надають. Крім того, до цього блоку належать знання про ступінь розвитку власних комунікативних умінь і навичок.

Проблему комунікативної компетентності концертмейстера, її вплив на профресійну діяльності ще мало досліджено. Зазвичай у педагогічній науці приділялося більше уваги предметному напряму педагогічного спілкування, ніж комунікативному, який вирізняється симптоматичним й інтерпретаційним характером. Інфрормація завжди втілюється в формі будь-яких знаків, знакових систем, інакше вона не може бути репрезентована людині. Особливо важливим є тлумачення і розуміння повідомлення (вербального і невербального) в контексті міжособистісної взаємодії. Діяльність концертмейстера в процесі різнобічного педагогічного спілкування відбувається у складній системі відносин «викладач - студент - концертмейстер». Від його комунікативної компетентності залежать легкість, результативність встановлення контактів у класі, ефективність вирішення різноманітних творчих задач. Цьому сприяє уміння стежити за реакцією викладача або студента, власна адекватна їі оцінка, отримання задоволення від спілкування, вміння сприймати й трактувати відгуки учасників спілкування, аналіз зорових і слухових сигналів, що надходять зворотним зв'язком. Володіючи певним рівнем комунікативної компетентності, концертмейстер долучається до спілкування, маючи певний рівень самосвідомості. Отже, показниками комунікативної компетентності концертмейстера вважаємо: 
- культуру вербальної і невербальної комунікації;

- експресію - вираження почуттів, переживань, виразності;

- культуру партнерської взаємодії;

- конорліктну компетенцію;

- наявність психологічних знань щодо закономірностей розвитку міжособистісних відносин і технології їх цілеспрямованого фрормування;

- наявність творчого підходу до системи педагогічно доцільних взаємин;

- здатність до конструктивного вирішення конорліктів і протиріч;

- наявність знань 3 психології спілкування [2, c. 21-23].

До показників комунікативної компетентності концертмейстера також можна зарахувати: досконале володіння складними комунікативними навичками і вміннями; знання норм, правил і обмежень у спілкуванні; володіння його технологією; знання звичаїв, традицій, етикету під час спілкування; дотримання ввічливості, вихованості; орієнтацію в комунікативних засобах. Позитивно-результативні відносини у процесі педагогічного спілкування можливі за умови, якщо концертмейстер отримав позитивний досвід взаємодії 3 колегами та студентами. Від того, наскільки компетентно побудоване спілкування в процесі профресійної діяльності фрахівця, залежать ступінь взаємодії учасників комунікації, задоволення концертмейстера, викладача і студента своєю працею, морально-психологічний клімат у класі і, як наслідок, результативність навчального процесу [3].

Висновки. Отже, становлення комунікативної компетентності концертмейстера відбувається за умов збагачення його знань щодо сутності комунікативної компетентності та ефективних способів міжособистісної взаємодії, особливої уваги до комунікативного питання в спілкуванні, проведення системної діагностики цього явища на всіх етапах власної трудової діяльності, стимулювання комунікативного саморозвитку, встановлення цін- нісно-особистісних відносини між учасниками комунікації та створення сприятливого психологічного клімату в колективі. Таким чином, комунікативна компетентність - це складний френомен, який удосконалюється впродовж педагогічної взаємодії з усіма суб'єктами освітнього процесу та стає чинником успішної професійної діяльності концертмейстера закладу вищої освіти.

\section{БІБЛІОГРАФІЧНИЙ СПИСОК:}

1. Амеліна С.М. Теоретико-методичні основи фрормування культури професійного спілкування у студентів вищих аграрних навчальних закладів : теорія і практика: монографрія. Дніпропетровськ, 2007. 360 с.

2. Волкова Н.П. Профресійно-педагогічна комунікація : навчальний посібник. Київ, 2006. 256 с.

3. Гуманістичний потенціал педагогічної комунікації. Книга для вчителя : наук.-метод. посібник / за ред. С.О. Мусатова. Київ, 2008. 96 с.

4. Зимняя И.А. Ключевые компетенции - новая парадигма образования. Высшее образование сегодня. 2003. № 5. 39 с.

5. Максименко С.Д. Технологія спілкування (комунікативна компетентність учителя: сутність і шляхи фрормування) / С.Д. Максименко, М.М. Заброцький. Київ, 2005. 112 c.

6. Рабецька Н.Л. Формування комуникативної компетентності майбутніх фрахівців соціономічної сфери у професійній підготовці : дис. ... канд. пед. наук : 13.00.04. Одеса, 2018. 294 с.

7. Рыданова И.И. Основы педагогики общения. Минск, 1998. 319 с.

8. Скалій Л.І. Поняття профресійної компетенції вчителя іноземних мов у застосуванні сучасних інфрормаційних технологій. Гуманізація навчально-виховного процесу. Збірник наукових праць. Слов'янськ, 2003. C. 293-296.

9. Тюріна В., Пляка Л. Профресійна компетентність як фрактор формування конкурентоспроможності майбутніх фрахівців. Молодіжна політика: Проблеми і перспективи. Збірник матеріалів VI Міжнародної науково-практ. конфр. 15-16 травня 2009 р. Дрогобич, 2009. C. 135-137.

10. Хомский Н. Аспекты теории синтаксиса. Москва, 1972. 259 с. 